\title{
Deterrence in Eastern Europe in Theory and Practice
}

\section{Darrell Driver}

United States Army War College, Carlisle Barracks, Pennsylvania, https://www.armywarcollege.edu/

\begin{abstract}
This article explores the continuities and changes between Cold War deterrence concepts and approaches and those being employed on NATO's Eastern flank today. It is argued that classic approaches to deterrence, curated in a rich Cold War intellectual tradition, have been clearly on display in NATO's responses to Russian aggression and threats, and it is possible to understand the decisions being made in Brussels and Alliance capitals through a consideration of such classical deterrence concepts as deterrence by denial and deterrence by punishment or direct versus extended deterrence. Concepts like these and others explored here remain useful. Nevertheless, important changes in the scope and nature of the threat must be considered, especially as this pertains to non-military aspects of deterrence and so-called hybrid or 'gray-zone' threats. This will require a merging of traditional concepts of deterrence with the more recent focus on developing a comprehensive approach to contemporary security challenges.
\end{abstract}

Keywords: deterrence, denial, NATO, Eastern Europe, hybrid threats.

Most people are familiar with the two primary symbols of the transatlantic Alliance: the acronym NATO or I'OTAN and the NATO star. However, there is also an equally old and venerable, if informal, NATO symbol that bears some consideration in any discussion of deterrence and defense: the hedgehog. First mentioned by Dwight Eisenhower in 1951, the first Supreme Allied Commander Europe (SACEUR) encouraged individual Allies to be capable of making themselves into a "hedgehog of defense" in order to buy the time NATO would need to come to their defense. Since the Russian annexation of Crimea in 2014, this long dis- 
carded symbol of deterrence has made a resurgence. However, while this necessary rediscovery of deterrent concepts is underway, there is also much that is different about deterrence and collective defense today that warrants consideration. Borrowing from Isaiah Berlin's famous "fox and the hedgehog" metaphor, ${ }^{1}$ changes in the contemporary security environment mean that NATO will require more of the fox's adaptiveness of thought and varied approach to problem-solving as it re-commits itself to a hedgehog-like focus on deterrence.

This article explores both the continuities and changes that warrant consideration in any discussion of deterrence and defense in today's Eastern Europe. I argue that classic approaches to deterrence have been at work in Allies' responses to Moscow's aggression, and it is possible to understand the decisions being made in Brussels and Alliance capitals through a consideration of these classic deterrence concepts. Nevertheless, important changes in the scope and nature of the threat must be considered, especially as this pertains to non-military aspects of deterrence and so-called hybrid or "gray-zone" threats.

\section{Concepts of Deterrence}

The concept of deterrence is perhaps as old as human conflict itself, but its intellectual "golden era" was cultivated in the climate of the Cold War from about 1946 to the late 1980s. This period saw the adoption of cornerstone contributions by figures such as Bernard Brodie, Herman Kahn, Thomas Schelling, and Glenn Snyder. ${ }^{2}$ Though the driving force behind much of the early work from this period was the advent of nuclear weapons, deterrence as a concept was quickly expanded to the conventional domain as well. ${ }^{3}$ Whether nuclear or conventional, the essence of deterrence, according to US joint doctrine, is "the prevention of action by the existence of a credible threat of unacceptable counteraction and/or belief that the cost of action outweighs the perceived benefits. ${ }^{4}$ Glenn Snyder described deterrence simply as "discouraging the enemy from taking military action by posing for him a prospect of cost and risk outweighing his per-

1 Isaiah Berlin, "The Hedgehog and the Fox: An Essay on Tolstoy's View of History," The Proper Study of Mankind: An Anthology of Essays, ed. Henry Hardy and Roger Hausheer (New York: Farrar, Straus, and Giroux, 1998). For a more recent use of the metaphor applied to strategy, see John Lewis Gaddis, On Grand Strategy (New York: Penguin Press, April 2018).

2 Bernard Brodie, ed., The Absolute Weapon: Atomic Power and World Order (New York: Harcourt, Brace and Company, 1946); Herman Kahn, On Thermonuclear War (Princeton: Princeton University Press, 1960); Thomas C. Schelling, Arms and Influence: With a New Preface and Afterward (New Haven: Yale University Press, 2008); Glenn H. Snyder, Deterrence and Defense: Toward a Theory of National Security (Princeton: Princeton University Press, 1961).

3 For a focused look at conventional aspects, see John J. Mearsheimer, Conventional Deterrence (Ithaca, N.Y.: Cornell University Press, 1983).

4 DOD Dictionary of Military and Associated Terms, US Joint Chiefs of Staff, Military and Electronic Library, http://www.jcs.mil/Portals/36/Documents/Doctrine/pubs/diction ary.pdf. 
spective gain." ${ }^{5}$ Deterrence differs from compellence, the other form of coercion, in that it does not seek to encourage another actor to do something, rather to get that actor to maintain the status quo, to "just keep doing what you are doing." ${ }^{6}$ From this basic observation about the purpose of deterrence grew a rich and diverse literature that would be impossible to explore fully in an article of this length. Instead, I would like to focus on few central concepts and approaches worth highlighting for the present problem set.

First, the literature draws a distinction between Immediate and General Deterrence. "Immediate deterrence, according to Patrick Morgan, "concerns the relationship between opposing states where at least one side is seriously considering an attack while the other is mounting a threat of retaliation in order to prevent it." 7 For this reason, Richard Lebow and Janice Stein label immediate deterrence "a strategy of conflict management" with one side attempting to dissuade the other from aggression. ${ }^{8}$ This can be contrasted with general deterrence, which Morgan describes as relating more "to opponents who maintain armed forces to regulate their relationship even though neither is anywhere near mounting an attack." ${ }^{9}$ With a few high tension exceptions, like the 1962 Cuban Missile Crisis, Lawrence Freedman argues that this "Iong haul" deterrence characterized the balance of power relationship and Cold War strategy. According to Freedman, "general deterrence is practiced in order to avoid having to practice immediate deterrence." 10

The second prominent concept in the literature has to do with the distinction between deterrence by punishment and deterrence by denial. Deterrence by punishment requires one to convince an adversary that any aggression, initially successful or not, will be met with a response that is unacceptably costly. This approach involves convincing the adversary of both the capability to impose such cost as well as the will to follow through, even in the face of further retaliation. Punishment is different from deterrence by denial, which seeks to demonstrate a credible ability to prevent the adversary from achieving desired objectives in the first place. The US Secretary of State from the early Cold War, Dean Acheson, described the practical difference this way, "we mean that the only deterrent to the imposition of Russian will in Western Europe is the belief that from the out-

5 Snyder, Deterrence and Defense, 35.

6 Robert J. Art and Kelly M. Greenhill, "Coercion: An Analytic Overview," in Coercion: The Power to Hurt in International Politics, ed. Kelly M. Greenhill and Peter Krause (New York: Oxford University Press, 2018), 5.

7 Patrick M. Morgan, Deterrence: A Conceptual Analysis (Beverly Hills, CA: Sage Publications, 1977), 28.

8 Richard Ned Lebow and Janice Gross Stein, "Beyond Deterrence," Journal of Social Issues 43, no. 4 (Winter 1987): 5-71.

9 Morgan, Deterrence: A Conceptual Analysis, 28.

10 Lawrence Freedman, "General Deterrence and the Balance of Power," Review of International Studies 15, no. 2 (April 1989): 199-210, quote on p. 204, https://doi.org/10.1017/S0260210500113002. 
set of any such attempt American power would be employed in stopping it [denial], and, if necessary, would inflict on the Soviet Union injury which the Moscow regime would not wish to suffer [punishment]." ${ }^{11}$ Of course, both of these effects are aimed at the mind of an adversary, with denial deterrence, according to Glenn Snyder, presenting "the enemy with a threat which is more easily calculable than punishment deterrence." 12

The third prominent distinction in the literature is perhaps the most straightforward: direct (or central) deterrence and extended deterrence. Direct deterrence refers to the ability to dissuade an adversary from attacking one's homeland. Extended deterrence is measured by the ability to include other states under that same deterrent umbrella. In the latter case, credibility challenges are prevalent. It is one thing to convince an adversary that one will respond if one's homeland is attacked, whether there be risk of future retaliation and escalation or not. It is quite another to convince an adversary that one will respond if an ally is attacked, thereby assuming retaliatory risk on behalf of others. Much of US effort in the Cold War was in convincing the Soviets of the credibility of the US threat to fight if European Allies were attacked. This was done both through strong statements of commitment and intent that Patrick Morgan called "mortgaging the president's honor." 13 It was also done by forward deploying troops into areas subject to Russian aggression and, in some cases, giving local commanders the authority to respond to an attack. The goal was to remove as much doubt as possible regarding the certainty that an attack on a NATO Ally would engender a response from the US, thereby making extended deterrence credible.

\section{Deterrence in Post-2014 Europe: Theory Meets Practice}

While the above review barely scratches the surface of a broad deterrence literature, it does offer a starting point for thinking about deterrence in contemporary Europe. While there was a point when this body of literature looked to be condemned, like the Cold War, to the dustbin of history, the 2014 Russian occupation of Crimea and fostering of instability in eastern Ukraine has once again put deterrence concepts back at the center of European security discussions. It is, therefore, worth considering how NATO efforts at deterrence since 2014 have taken shape and how deterrence theory helps explain these efforts.

In response to what was called the first forcible change of European borders since World War II, the US responded quickly to demonstrate its commitment to NATO territorial sovereignty. The US Operation Atlantic Resolve (OAR) projected a line of small units across NATO's eastern flank as a visible symbol of US resolve.

11 Dean Acheson, Power and Diplomacy (New York: Atheneum, 1962), 85.

12 Glenn H. Snyder, Deterrence by Denial and Punishment, Woodrow Wilson School Research Monograph (Princeton University, January 1969), 5.

13 Patrick M. Morgan, Deterrence Now (Cambridge, UK: Cambridge University Press, 2003), 15-16. 
Visits by both President Barack Obama and Vice President Joe Biden included an "ironclad" commitment to the security and sovereignty of NATO Allies, and the US Congress appropriated \$1B in European Reassurance Initiative (ERI) funds to pay for the enhanced posture of US forces in Europe and begin bringing additional rotational forces from the US. ${ }^{14}$ In word and action, Washington responded to Eastern NATO Allies' concern that the moment called for immediate deterrent steps by signaling the US's continued commitment to extended deterrence in Eastern Europe, if only with small numbers of initial forces.

NATO likewise acted collectively to demonstrate resolve in the east. The NATO Readiness Action Plan was developed immediately to implement a range of short-term assurance measures for Eastern Allies and longer-term adaptation measures to improve the deterrence posture of the Alliance. At the 2014 Wales Summit of Heads of State and Government (HOS/G), Allies agreed to a dramatic expansion of the NATO Response Force (NRF), including the development of a Very High Readiness Joint Task Force (VJTF) that could put a brigade's worth of combat power on the ground within 5-7 days of activation. Importantly, the VJTF would be comprised of units from 10 to 15 Allies, signaling a unified response to any aggression that triggered its deployment. We also saw this inclination to staff units with broad representation from across the Alliance in the composition of the NATO Force Integration Units (NFIUs), also agreed at Wales. At the Warsaw Summit two years later, this logic of fielding multi-flagged units to demonstrate NATO unity was extended further, with the advent of enhanced Forward Presence (eFP) in the Alliance's northeast and tailored Forward Presence (tFP) in the southeast.

Thus, like the US's OAR, the VJTF, eFP, and tFP meant that other NATO Allies, too, were signaling a commitment to extended deterrence on the Alliance's eastern flank and, like the US, the combat power of these formations was far from decisive. A 2016 RAND Corporation study stated its findings bluntly, "as currently postured, NATO cannot successfully defend the territory of its most exposed members." ${ }^{15}$ This was far from an epiphany. The force posture in the Baltics was particularly problematic and served as a special point of emphasis for the same RAND study. "Across multiple games using a wide range of experts," according to the study's authors David Shlapak and Michael Johnson, "the longest it has taken Russian forces to reach the outskirts of Tallin and Riga is 60 hours." ${ }^{16}$ RAND was evaluating the Alliance on its ability to deter by denial in the Baltics, but one might view Allies' efforts, at least through 2016, as working to demonstrate a commitment to extended deterrence through deterrence by punishment. That is, broad Allied "skin in the game" would ensure that any act of aggression would

14 Congressional Research Service, "The European Deterrence Initiative: A Budgetary Overview," In Focus, August 8, 2018, https://fas.org/sgp/crs/natsec/IF10946.pdf.

15 David A. Shlapak and Michael W. Johnson, "Reinforcing Deterrence on NATO's Eastern Flank: Wargaming the Defense of the Baltics" (Arroyo, CA: RAND Corporation, 2016), 1.

16 Shlapak and Johnson, "Reinforcing Deterrence on NATO's Eastern Flank." 
engender a unified Alliance response. If NATO could not prevent an initial decision, forward-deployed NATO troops and initial rapid reinforcement would make a broader conflict and, therefore, NATO retaliation unavoidable.

Meanwhile, both individual Allies and the Alliance have continued to work on longer-term NATO adaptation measures that would allow the Alliance to develop a credible deterrence by denial capability. The HOS/G commitment at Wales to move their nations toward spending 2 percent of Gross Domestic Product on defense and spending 20 percent of the defense budget on modernization and equipment was one important step to developing more credible military capabilities. ${ }^{17}$ For its part, the US has responded by dramatically increasing defense expenditures earmarked for Europe, increasing ERI spending from \$1 Billion in 2015 to $\$ 4.8$ Billion in 2018 , with a request of $\$ 6.5$ Billion for $2019 .{ }^{18}$ In fact, ERI itself was renamed from European Reassurance Initiative to European Deterrence Initiative (EDI) in the 2017 legislation. This money has gone to increase presence of rotational forces, expanded exercises and training, enhanced prepositioning of equipment, improved infrastructure, and the building of partner capacity.

NATO has followed suit, initially allocating $\$ 200$ Million toward the development of a prepositioning site for US equipment in Poland, ${ }^{19}$ and, at the 2018 Brussels Summit, NATO further sharpened its focus on deepening the "NATO bench" and improving readiness in order to be capable of fielding significant combat forces in a shorter period of time. The so-called "four-30s" plan commits Allies to making available 30 troop battalions, 30 squadrons of aircraft, and 30 warships on 30 days notice-to-move. ${ }^{20}$ Along with the development of ready units, NATO has also been working on improving intra-European mobility. Ideas like the development of an EU "Schengen Zone-like" collection of countries that commit to expediting military mobility have begun to take shape. ${ }^{21}$ Currently, the Alliance is beginning to grapple with the much tougher and more costly task of improving the physical infrastructure required to enable mobility. All of these efforts suggest a transition from an initial focus on establishing the credibility of NATO threats to respond vigorously to any aggression against NATO Allies, ini-

17 North Atlantic Treaty Organization (NATO), "Wales Summit Declaration," September 5, 2014, para 14, https://www.nato.int/cps/ic/natohq/official_texts_112964.htm.

18 Congressional Research Service, "The European Deterrence Initiative."

19 Department of Defense, "Military Construction Program: FY 2019 Budget," February 2018, 9, https://comptroller.defense.gov/Portals/45/Documents/defbudget/fy2019/ budget_justification/pdfs/11_NATO_Security_Investment_Program/FY19_NSIP_JBook_Final.pdf.

20 North Atlantic Treaty Organization (NATO), "Brussels Summit Declaration," July 11, 2018, para 14, https://www.nato.int/cps/en/natohq/official_texts_156624.htm.

21 European Union, External Action Service, "Defence: EU Moves on Military Mobility," March 28, 2018, https://eeas.europa.eu/headquarters/headquarters-Homepage/ 42226/defence-eu-moves-military-mobility_en. 
tially successful or not (deterrence by punishment), to a more calculable ability to deny an aggressor the prospect of an initial, quick victory.

\section{Deterrence Theory as Guide to Future Practice}

If we can say, then, that current defense work in Eastern Europe fits well with existing deterrence literature, what might this literature have to say about necessary future work? To answer this question, it is useful to consider some of the reasons past deterrence efforts have failed. Alexander George and Richard Smoke's 1974 typology identifies three patterns for how an adversary might trigger a deterrence failure: the fait accompli attempt, the limited probe, and controlled pressure. ${ }^{22}$ The differences are determined by the level of risk an aggressor is prepared to take. An attempted fait accompli attack comes with the most risk, but it can, according to George and Smoke, be "the most rational" approach if the initiator believes the adversary is unable to prevent the action and does not value the disputed territory enough to warrant the necessary investment of blood and treasure to reverse the initial decision. ${ }^{23}$ Observers point to the 2014 annexation of Crimea as the implementation of a fait accompli policy. ${ }^{24}$ Recognizing the threat posed by such adventurism in the Cold War, Glenn Snyder evaluated NATO defense posture in Europe and concluded that a deterrence by denial force need not be capable of holding out indefinitely or defeating an invader outright, but it did need to be strong enough to convince the Soviets of the Allies' commitment to resist. The operative question, then, in contemporary Eastern Europe is how much and what kind of force is needed to achieve this goal.

A recent report from the Center for European Policy Analysis led by former US Army Europe Commander, Lieutenant General (retired) Ben Hodges, offers some answers to this question, highlighting the requirement for (1) effective early warning, (2) capable national forces, and (3) adequate infrastructure and prepositioned supplies. ${ }^{25}$ First, according to the report, early warning in the east is critical to gaining a window of opportunity within which the Alliance can communicate its resolve through additional force deployments, like that of the VITF and the broader 40,000 troop strong NATO Response Force. Put another way, the more advanced warning NATO has to transition from a general to an immediate deterrence posture, the greater the opportunity for the signaling necessary to eliminate any potential Russian misperception or miscalculation regarding Allies' commitment to collective defense. Second, capable national forces are es-

22 Alexander L. George and Richard Smoke, Deterrence in American Foreign Policy: Theory and Practice (New York: Columbia University Press, October 1974), 534-547.

23 George and Smoke, Deterrence in American Foreign Policy, 537.

24 Zdzislaw Sliwa, "Poland: NATO's East Frontline Nation," in Deterring Russia in Europe: Defence Strategies for Neighbouring States, ed. Nora Vanaga and Toms Rostoks (Routledge, 2018), 217-236.

25 Ben Hodges, Janusz Bugajski, and Peter B. Doran, "Securing the Suwałki Corridor: Strategy, Statecraft, Deterrence, and Defense" (Washington, DC: Center for European Policy Analysis, July 2018), 4. 
sential to bolstering the east and making eastern NATO Allies an uninviting military target in the first place. The importance of a strong national defense capability is enshrined in NATO's founding treaty, which states in Article 3 that parties to the treaty will, "separately and jointly, by means of continuous and effective self-help and mutual aid, [...] maintain and develop their individual and collective capacity to resist armed attack." ${ }^{26}$ One especially encouraging example of both of these principles is the potential of strengthened cooperation under the socalled B9+ (Bucharest Cooperation) arrangements, in which the nine eastern Alliance states (Estonia, Latvia, Lithuania, Poland, Czech Republic, Slovakia, Hungary, Romania, and Bulgaria) agree to work collectively on shared challenges such as readiness and interoperability. Third, because it is unrealistic to expect NATO to maintain a forward Cold War-like posture of substantial permanently stationed forces, ${ }^{27}$ prepositioned supplies and improved transportation infrastructure are critical to enabling rapid reinforcement. In order to incentivize greater investment here, Lieutenant General (retired) Ben Hodges and his coauthors recommend that NATO develop parameters whereby Allies could count public spending on certain "dual-use" (military and civilian) infrastructure projects toward the agreed NATO 2 percent guideline. ${ }^{28}$ While proposals like this do not have the necessary political support at the moment, they do demonstrate a growing awareness of the critical importance of military mobility to preventing any Russian consideration of a fait accompli approach. Efforts to demonstrate improved mobility and responsiveness are manifest in an expanded Alliance exercise regime, with the 2017 multinational exercise Saber Guardian providing an important test of the concepts in southeast Europe and the 2018 NATO exercise Trident Juncture doing the same for the north. ${ }^{29}$

As NATO has been making progress on the prevention of potential fait accompli failures, it must also keep in mind what George and Smoke refer to as a limited probe approach. In this threat to deterrence, an initiator "creates a controlled crisis in order to clarify the defender's commitments." 30 Rather than an all-out attempt to change the status quo and then challenge the defender to reverse the decision, as in the previous example, an initiator uses a controllable, calculable, and reversible limited probe to test a defender's resolve while at-

26 "The North Atlantic Treaty," Article 3 (Washington, DC: NATO, April 4, 1949), https://www.nato.int/cps/ie/natohq/official_texts_17120.htm.

27 In fact, the Alliance continues to abide by the spirit of the NATO-Russia founding act, which commits NATO to collective defense through interoperability and reinforcement, rather than "permanent stationing of substantial combat forces." There is no consensus in the Alliance to change this position. "Founding Act on Mutual Relations, Cooperation and Security between NATO and the Russian Federation" (Paris, France: North Atlantic Treaty Organization, May 22, 1997), https://www.nato.int/cps/su/ natohq/official_texts_25468.htm.

28 Hodges, Bugajski, and Doran, "Securing the Suwałki Corridor," 8.

29 Planning is underway for SABER GUARDIAN 2019, an Allied exercise in southeast Europe of equal or greater scope and scale than the 2017 event.

30 George and Smoke, Deterrence in American Foreign Policy, 540. 
tempting to limit the risk of a broader conflict. Such an approach can be especially problematic for an Alliance whose credibility rests on the treaty commitment that an attack on one will be viewed as an attack on all. Ambiguities surrounding the question of what constitutes treaty language like "armed attack" or an Ally's commitment to take "such action as it deems necessary" ${ }^{31}$ could turn a limited probe into a poison pill that fractures Alliance unity over how to deal with the transgression.

Here again, communicating 'red-lines' is critical. As Robert Art and Kelly Greenhill argue, "a defender must make crystal clear to any potential attacker what the defender's red lines are by clearly stating its commitment, [... and] by pointing out the costs the challenger will bear should it cross the red lines." 32 Future NATO military exercises and political level crisis management exercises might, therefore, look for creative ways to build limited probe responses into exercise scenarios. Both individually and collectively, Allies might also develop a broader list of military and non-military crisis response measures for different limited probe scenarios. These measures work best when there is broad consensus on what response measures are available and how and when they would be implemented. For this reason, US, NATO, and European Union (EU) cooperation on such work, especially regards non-military measures, would be especially beneficial. Where a priori consensus on response measures is not possible, strategic ambiguity will need to be limited through collective statements and clear posturing. The statements and actions of Alliance leadership, especially the US President, are critical in these moments. ${ }^{33}$

The final threat to deterrence, according to George and Smoke, can be seen in patterns of controlled pressure. This approach offers the initiator the least amount of risk and is employed in situations in which the initiator views the defender's commitment as "unequivocal," compared to "pattern one, the initiator's belief is that there is no commitment; in pattern two he believes that there is uncertainty or ambiguity regarding a commitment by the defender." ${ }^{34}$ Pattern three, therefore, can be appealing to an adversary who believes he has a particular asymmetric advantage against which the defender cannot offer adequate defense. George and Smoke point to continued Soviet pressure on West Berlin during the Cold War as an attempt to leverage the Soviet geographic advantage in surrounding the historic German capital. The purpose was to gradually erode western commitment to a free West Berlin and exacerbate tensions in the Alliance over the level of commitment NATO should demonstrate on the issue. One sees a similar approach today in Georgia, Ukraine, the Baltics, and Black Sea region, albeit with important differences in tactics across each case.

\footnotetext{
31 "The North Atlantic Treaty," Article 5.

32 Art and Greenhill, "Coercion: An Analytic Overview," 12.

33 Morgan, Deterrence Now, 15-16.

34 George and Smoke, Deterrence in American Foreign Policy, 543.
} 
The controlled pressure approach, along with select limited probes, can also be seen in a broad range of activities carried out below the level of conflict. These so-called "gray zone" or "hybrid" approaches are generally characterized by "activity that is coercive and aggressive in nature, but that is deliberately designed to remain below the threshold of conventional military conflict and open interstate war." 35 This makes the strategy ideal for controlled pressure efforts to defeat deterrence. It can be waged in a traditional geographic context through proxies, as in Eastern Ukraine, or through economic coercion, information warfare, sabotage, and, especially, cyber-attacks. Moreover, as traditional NATO deterrence efforts strengthen, this controlled pressure approach to undermining deterrence through gray zone efforts becomes more appealing to those wishing to change the status quo while avoiding open conflict. It is a new front in a more classic deterrence stand-off that poses one of the more difficult challenges for contemporary deterrence.

\section{The Grey-Zone and the Stability / Instability Paradox}

With new technologies opening up new opportunities for a controlled-pressure strategy to defeat Alliance deterrence efforts, the Alliance has witnessed the emergence of what might be termed a "stability-instability paradox." The term was first coined in the 1960s to describe the way in which nuclear weapons constrained great power war, creating a level of overt stability even as adversarial states waged a low level but frenetic campaign of influence and proxy wars. A similar dynamic can be seen in the way strengthened Alliance conventional deterrence measures backed by extended nuclear deterrence have led adversaries to look for ever more controllable and calculable ways to exert pressure on deterrence regimes. Put another way, while NATO conventional deterrence efforts appear to be settling Eastern Europe into a general deterrence state of affairs, grey-zone probes, assaults, and campaigns continue to call for more crisis management-like responses, including actions to bolster immediate deterrence. Though these basic dynamics can be seen in examples across different hybrid spheres of action, cyber and the information sphere are several areas worth highlighting.

"The biggest problem in cyber," according to Estonia's former President Toomas Ilves, "remains deterrence. We have been talking about the need to deal with it within NATO for years now." ${ }^{36}$ Indeed, Richard Clarke and Robert Knake go so far as to argue that deterrence theory simply does not transfer very well

35 Hal Brands, "Paradoxes of the Gray Zone," Social Science Research Network Electronic Journal (January 2016), 1, http://dx.doi.org/10.2139/ssrn.2737593.

36 Quoted in Joseph S. Nye Jr., "Deterrence and Dissuasion in Cyberspace," International Security 41, no. 3 (Winter 2016/2017): 44-71, quote on p.44, https://doi.org/ 10.1162/ISEC_a_00266. 
to the cyber domain, ${ }^{37}$ and, where there has been theory transfer, the focus has generally been on deterrence by denial through network defenses and more resilient systems. In fact, the former US Deputy Secretary Defense William Lynn offered this view in arguing that "deterrence will necessarily be based more on denying any benefit to attackers than on imposing costs through retaliation." 38 This has also been the primary approach by NATO, initially focusing on the protection of NATO networks and enhancing resilience through education, mutual assistance, and cyber rapid reaction teams. ${ }^{39}$ However, at Warsaw, NATO adopted cyberspace as a domain of operations, and the 2018 Brussels Summit resulted in an agreement to establish a Cyberspace Operations Center and to "continue to work together to develop measures which would enable us to impose costs on those who harm us." 40 Thus, despite some challenges, NATO has continued to adapt deterrence concepts to the emerging cyber domain of operations, evolving from a focus on defending NATO networks to assisting Allies with resilience and, eventually, a recognition of the need for a deterrence by punishment capability.

Allies' efforts have also begun to signal a more holistic approach to the application of deterrence concepts in cyber. According to Zdzislaw Sliwa, Poland's publication of its 2015 "Information Security Doctrine of the Republic of Poland" was an effort to establish a deterrence by denial posture. ${ }^{41}$ Nevertheless, the document also highlights the requirement for "pursuing active cyberdefence, including offensive actions in cyberspace, and maintaining readiness for cyberwar." 42 Owing to a broad 2007 Russian cyber-attack, Estonia is perhaps the most forward-leaning Ally on the question of cyber. As a result, the 2017 defense development plan commits the country to the creation of "a national Cyber Command to develop both defensive and offensive cyber capabilities." 43 Finally, despite Deputy Defense Secretary Lynn's earlier comments, the United States' most recent 2018 cyber strategy offers a similar recognition that deterrence in the cyber domain requires both denial and punishment capabilities, arguing that

37 Richard A. Clarke and Robert K. Knake, Cyber War: The Next Threat to National Security and What to Do About It (New York: HarperCollins, 2010), 189.

38 William J. Lynn III, "Defending a New Domain: The Pentagon's Cyberstrategy," Foreign Affairs 89, no. 5 (September/October 2010): 97-108.

39 North Atlantic Treaty Organization, "Cyber Defence," July 16, 2018, www.nato.int/ cps/en/natohq/topics_78170.htm.

40 North Atlantic Treaty Organization, "Brussels Summit Declaration," July 12, 2018, para 20, https://www.nato.int/cps/ic/natohq/official_texts_156624.htm.

41 Sliwa, "Poland: NATO's East Frontline Nation."

42 National Security Bureau (Biuro Bezpieczenstwa Narodowego), "Cybersecurity Doctrine of the Republic of Poland," January 2015, accessed February 4, 2018, http://en.bbn.gov.pl/en/news/400,Cybersecurity-Doctrine-of-the-Republic-ofPoland.

43 Henrik Praks, "Estonia's Approach to Deterrence," in Deterring Russia in Europe: Defence Strategies for Neighboring States, ed. Nora Vanaga and Toms Rostoks (New Yourk: Routledge), 217-235. 
"activity that is contrary to the responsible behavior in cyberspace is deterred through the imposition of costs through cyber and non-cyber means." 44 This latter point bears highlighting. Deterrence by punishment in the cyber domain may rely on a symmetric cyber response, but it might also include other asymmetric retaliatory measures, as with the imposition of US economic sanctions on Russia in response to meddling in the 2016 US elections. Achieving effective cyber deterrence will require Allies to continue exploring how both symmetric and asymmetric response options might best be employed and signaled ahead of time.

Being especially vulnerable, Eastern European states should continue to explore how they might adapt their own cyber strategies and deepen cooperation with other Allies in the cyber domain. Both the Bulgarian and Slovenian cyber strategies were developed in 2016, while Hungary and Romania's strategies date from 2013, before the 2016 NATO Cyber Defense Pledge. The establishment of cyber defense as an Alliance domain of operations, the affirmation that cyber defense is a part of NATO's collective defense core task, and the creation of a NATO Cyberspace Operations Center all speak to the expansion of concern and cooperation in this area. Ideas, like those put forward by the Atlantic Council of Bulgaria, to establish a cyber and hybrid threats response center should be considered as ways to foster continued interoperability and coordination.

A second hybrid challenge for NATO can be seen in the way Moscow has targeted media markets to influence messaging toward Russian political and economic interests. Findings from a recent Center for the Study of Democracy report describe pro-Russian oligarchic networks that exert broad control over Black Sea media markets either through outright ownership or the cultivation of other forms of economic dependency. ${ }^{45}$ This has resulted in more-or-less consistent Moscow-directed misinformation and message spin in the impacted countries. The case of Bulgaria is especially enlightening. Having made foreign media investment illegal, national media markets were rapidly dominated by a handful of local actors who serve as a vehicle for illicit external funds. Rather than preventing outside influence, the measure ensured that foreign influence would be furtive and less-transparent, facing little market competition.

As these and other hybrid threats pose an ever greater challenge, methods of dealing with them have largely followed a deterrence by denial path, including the strengthening of political, economic, and societal resilience. Indeed, the Center for the Study of Democracy calls for a variety of EU sponsored measures to bolster Black Sea area media resilience, like programs to improve journalistic standards and prevent so-called media capture by malign external actors. Simi-

44 "National Cyber Strategy of the United States of America," (Washington, DC: The White House, September 2018), 3, https://www.whitehouse.gov/wp-content/ uploads/2018/09/National-Cyber-Strategy.pdf.

45 Center for the Study of Democracy (CSD), Russian Influence in the Media Sectors of the Black Sea Countries: Tools, Narratives, and Policy Options for Building Resilience (Sofia, Bulgaria: Black Sea Trust for Regional Cooperation and the German Marshall Fund, 2018). 
larly, Radio Free Europe returned to both Romania and Bulgaria in December 2018 as a result of growing concern about the health of a free press in the region. ${ }^{46}$ While these measures are sorely needed, deterrence by punishment approaches might also be considered. Such disincentives might include aggressive legal action and sanctions for individuals or groups that violate national laws. Here again, a cyber and hybrid threats response center like that proposed by Bulgaria's Atlantic Council could make important contributions to the effort and would have the advantage of plugging into a community of interest doing similar work across Europe. ${ }^{47}$

\section{Conclusions}

Though deterrence theory is certainly no panacea for either the conventional or hybrid threats that face Eastern Europe, a consideration of some of the deterrence theory's key principles can help organize thinking and identify additional questions worth considering. One way of understanding Alliance efforts since 2014 has been to address the more immediate threats to deterrence first, preventing the fait accompli attack and drawing red-lines against limited probe efforts. This was done initially by establishing the expectation that rapid reinforcement and forward deployment would guarantee Alliance retaliation, deterring further adventurism through the prospect of punishment. The great challenge in this approach was in making the likelihood of punishment and the US commitment to extended deterrence credible. This effort has since been augmented by more sustained efforts to field capabilities that can oppose local, geographic Russian force advantages through stronger national forces, early warning, rapid mobility, and prepositioned equipment. This move toward deterrence by denial requires greater pre-crisis preparation of Eastern European defenses but can be more reliable in that it is easier for an adversary to calculate the risk aggression would entail. 48

Nevertheless, even as these efforts continue to mature, controlled pressure challenges to NATO deterrence means that Alliance unity and resolve are under persistent assault. Individually, Allies are alive to the danger, and, collectively, the Alliance is coming to terms with the role NATO might play in addressing greyzone threats. What are the symmetric and asymmetric capabilities, response options, and crisis response measures that should be available? Do such capabilities belong in the NATO Defense Planning Process? How to ensure complementarity between individual Allies, NATO, and the EU? What is the role of NATO, including

46 Eugen Tomiuc, Eugen Tomiuc "RFE/RL to Launch News Services in Romania, Bulgaria," RadioFreeEurope/RadioLiberty, July 19, 2018, https://www.rferl.org/a/rfe-rl-tolaunch-news-services-in-romania-bulgaria/29376248.html.

47 The Hybrid Center of Excellence in Finland and Cyber Center of Excellence in Estonia are two important examples for where multinational cooperation might be leveraged to advance national work.

48 Snyder, Deterrence by Denial and Punishment, 5. 
Article 4 consultations, in bringing visibility to controlled pressure tactics? These are but a few of the questions for future work.

While all of this has to do with the one big idea of the hedgehog, deterrence, it also suggests that the application of deterrence in the contemporary security environment requires some of the more wide-ranging and innovative approaches of the fox. To borrow a phrase from another NATO playbook, the application of $21^{\text {st }}$ Century deterrence will require a comprehensive approach. This includes a comprehensive approach to resilience (deterrence by denial) and a comprehensive approach to imposing proportional costs on aggressors (deterrence by punishment). ${ }^{49} \mathrm{~A}$ workable strategy to do both would better enable Allies to deter on both ends of the conflict to the competition spectrum. This will demand both persistence and adaptiveness to accomplish enduring goals with new tools to employ against varied threats. It will require the instincts of both the hedgehog and the fox.

\section{Disclaimer}

The views expressed are solely those of the author and do not represent official views of the PfP Consortium of Defense Academies and Security Studies Institutes, participating organizations, or the Consortium's editors.

\section{Acknowledgment}

Connections: The Quarterly Journal, Vol. 18, 2019 is supported by the United States government.

\section{About the Author}

Colonel Darrell Driver, U.S. Army, is an Associate Professor and the Director of European Studies at the U.S. Army War College. His previous positions have included Director of NATO Support for U.S. European Command, Defense Policy Advisor to the U.S. Mission to NATO, Senior Fellow and Faculty Member at the George C. Marshall European Center for Security Studies, and Assistant Professor of Political Science at the U.S. Military Academy. He is the author of a number of articles and book chapters on subjects related to European security and civilmilitary relations. He holds a PhD (2006) in Political Science from Syracuse University.E-mail: darrell.w.driver.mil@mail.mil.

49 In fact, Chris Kremidas Courtney describes hybrid warfare as the "comprehensive approach in the offense." For more on this, see Chris Kremidas Courtney, "Hybrid Warfare: The Comprehensive Approach in the Offense," Friends of Europe: Europe's World, December 2018. 